\title{
An Untold Pandemic: Triple Burden of Working Women during COVID-19 Pandemic in Dhaka, Bangladesh
}

\author{
Anika Intesar \\ Bangabandhu Sheikh Mujibur Rahman Science and Technology University, Bangladesh
}

\begin{abstract}
This anthropological experimentation illustrates the cause and consequence of how triple roles of working mothers in Bangladesh become their utmost burdens. By emphasizing their life experiences through interviewing and case studies, this paper depicts how the recent COVID-19 pandemic, in turn, creates an unreported devastation in their lives. In relation to the study objectives, women from different occupations and age-groups are chosen to demonstrate the background of this study. Traditionally, women perform triple roles including reproductive works by bearing and raring children, household chores, maintaining workplace and community activities. Although these activities require significant amount of time, energy and dedication, they are highly undervalued, unpaid and unnoted. At the same time, these are merely considered as 'real works'. Moreover, the resent coronavirus issue makes the situation even worse for them. More precisely, this study focuses on an untold affliction of bearing triple burdens of working mothers in this developing country.
\end{abstract}

Keywords- triple role, triple burden, pandemic, working mother, stress, anxiety.

\section{INTRODUCTION}

Qhe is water, soft enough to offer life, tough enough to drown away", Rupi Kaur, a young poet from Nepal wrote this to portray the image of woman whom she sees around her everyday life. Women, knowing that life has different colors with ups and downs, can adapt well and bounce back quickly in times of difficulty. Though life is not bed of roses for anyone, women dismally face uttermost challenges throughout their lives. Those who work both inside and outside of their homes, experience stressful situations while trying to make a balance between their traditional role of homemaker and extra role of productive worker. Moreover, the ongoing corona virus event increases their vulnerability and become a worsening burden until the pandemic is well under control (McLaren and others, 2020). This is, no doubt, a real pandemic for women which is largely untold and uncounted. This anthropological work, in fact, attempts to locate the nature of that untold pandemic by drawing upon the concept of 'women's triple burden' to theorize their roles in productive, reproductive and community activities in the context of corona virus outbreak in Bangladesh. In a nutshell, it examines how the roles and responsibilities of women can be responsible for creating their own burdens.
Regardless of where a person looks, it is always women who bear much responsibility for themselves, home, family, kins and the surroundings. For centuries, women are the only one for whom reproductive work is meant for. Women who choose to work outside of their homes are burdened with numerous workload and responsibility. Even with sufficient family support and friendly working environment, working mothers experience stress. Moreover, women perform different community works on a regular basis for the betterment of their community. Thus, reproductive works along with productive and community works increase their workload for a lifetime. In addition to this, the recent outbreak of COVID-19 makes women one of the worst victims both physically and mentally. It increases their sufferings and workloads of reproductive work, maximizes pressure of productive work and decreases their interest in community work. This increased amount of work pressure can be hazardous for their physical health and working restlessly in both inside and outside of home during a panic situation is harmful for their mental health as well. As a result, triple roles of women miserably become their triple burdens during corona virus outbreak. In other words, woman's life goes through an untold disaster during an ongoing pandemic.

\section{LITERATURE REVIEW}

\section{Conceptualizing the Status of Women in Bangladesh}

As a developing South-Asian country, Bangladesh is the $8^{\text {th }}$ most populous nation in the world with US $\$ 5852$ per capita income (World Economic Outlook database, 2021). Since the country's independence in 1971, She faces tremendous challenges and gender issue is one of them. In postindependence era, women in this region began to experience increase in education, employment, empowerment, health care, nutrition, social and political rights, economic freedom and many other opportunities. At present, Bangladesh has got female Prime Minister, female Speaker of Parliament and female Leader of the Opposition at the same time. In Bangladesh, $49.42 \%$ of the population is women (World Population Prospects. 2019) and most of them live in rural areas. Here, only $36.3 \%$ entered in labor force in (Raihan and Bidisha, 2018). In this country, rural women engage in traditional home-based productive works such as small cultivation, fishery and husbandry, seasonal post-harvest 
activities etc. Their economic contribution, with limited access to capital and acute poverty, is largely unacknowledged. This situation is little better in urban areas. Urban educated women enter in public and private job sectors, teaching, banking, trade, sales worker, business and self-employment such as handicraft, tailoring, drawing, embroidery, boutique, food making and selling, cane and bamboo crafting etc. But some are found working in unorganized sectors such as maidservant, street beggar, prostitution etc. Also, the growth of factory and garment industry opens the door of employment for many women. The competition in the job market proves that women are rapidly entering professional world. However, their contributions in national economy are largely underacknowledged unlike men.

In Bangladesh, like Ortner (1972) argued, women occupy "secondary status" in the society and seen as inferior to men. This collective situation of women around the country is the same. The identity of women is stereotype with the traditional mindset of people which is shaped by the patriarchal social pattern. For example, men frequently used to introduce women as their wives or 'mothers' of their children as if they do not have any other identity. Again, a non-working mother is generally addressed as a 'housewife' as if she does not have any other work to do. Further, women's status is determined frequently by the status of their husband such as Major's wife, Principal's daughter etc. In Bangladesh, women are traditionally portrayed as soft, kind, humble and muted group (Ardener, 2005). They give birth to children, take care family members, manage household work and work as unpaid family worker. These reproductive activities are taken for granted only for women for centuries. But these works confined women to the private sphere, defining home as 'women's place'. Since Rogers (2005) called it "the domestication of women", meaning women is confined in a domestic sphere or home which is undervalued, unpaid and invisible. Though reproductive works are crucial for human survival, it is seldom considered as 'real work'. Again, women are found performing various roles for the betterment of whole community such as arranging social events and ceremonies such as birthday party, dinner parties on special occasions etc., as well as managing community resources such as kindergarten, supporting poor and ill members, first aid service etc. While incomegenerating productive works are their works, other works are their duties even though these works require sufficient amount of time and energy which never crossed people's mind. This gender division of labor imposes workload and burden on women, hampers their full potentials and perpetuates their subordination in the society.

It is sometimes believed that women's reproductive workload can prevent them from participating in productive roles, including both inside and outside of their houses. To the contrary, it is assumed that working women are burdened with time poverty and usually spent less time on reproductive works than a non-working mother. For example, working mother cannot continue breastfeeding and rearing their children in the same way non-working mothers do. Also, women get 6 months of maternity leave from their work in Bangladesh which creates long professional gap with workplace and colleagues. Moreover, in a family where both parents are employed, women are overburdened with multiple tasks. For example, a working mother wakes up early, cook and serve, go for work, come home and work for household and goes to bed at midnight. This routine is maintained repeatedly day after day. Thus, entering professional world creates a vice-versa dilemma and tons of burdens on their mental health. As a result, they face debilitating choice of compromising either their career or family responsibilities or fight between the two.

\section{Covid-19: A Recent Pandemic}

Corona virus, called COVID-19, is a type of virus emerged in December 2019 in Wuhan, China. It has caused a global pandemic situation by affecting 218 countries with an alarming death rate. It is responsible for causing contagious and sometimes debilitating respiratory illness including dry cough, fever, sore throat, breathing difficulty, loss of taste or smell, diarrhea, headache, fatigue, nausea, runny nose, kidney failure, even death. People with pre-existing medical conditions such as diabetics, heart disease, high blood pressure are in serious threat from it. As there is no $100 \%$ effective and no-risk vaccines or medical treatments yet, prevention is the best option. Wearing mask, cleaning hands frequently, safe social distance by staying at home etc. can prevent the spread of corona virus.

Globally there are $16,52,20,713$ confirmed cases of COVID19, including 34,24,469 deaths (Government of Bangladesh, 2021). In Bangladesh, the first case of COVID-19 was confirmed on $8^{\text {th }}$ March by IEDCR. The government announced a nationwide lockdown from 23rd March. Since then, the situation did not get any better. There are 7,83,737 confirmed cases of corona virus, including 12,248 death cases (Government of Bangladesh, 2021). Undoubtedly, this attack of this deadly and contagious virus has been a horrible experience for Bangladesh throughout the year.

\section{THEORETICAL UNDERPINNING:}

Sherry B. Ortner, in "Is female to male as nature is to Culture?" (1972), argued that all human cultures favor male instead of female. As women have the ability to bear and nourish children, they give birth and create new life. Also, their extreme emotional psyche and their domestic social roles such as cooking, childcares etc. make them as 'closer to nature' as humanly possible. To the contrary, men are more associated with culture. Thus, the human mindset that human nature is inferior to culture, is responsible to portray women as inferior to men. For her, this secondary status of women is "true universals, a pan-cultural fact." This is true for the situation of majority of women in Bangladesh.

The idea of public-private dichotomy can be useful for this study to relate with her theory as well. The discourse within 
anthropology of feminism shows that nearly in all societies women have always been a part of private sphere while men dominate public one (Moore, 1988). In private sphere where women are confined to home and acquire the characteristics of "muted group" (Ardener, 2005). Unlike men who are always the subject to discuss, women are silenced by the structure of dominance, educational status, religious doctrines, stereotypical traditional belief and norms, decision making power and so on. In Bangladesh, as this study shows, the picture is even worse due to traditional practice of patriarchy. Though women consist of about half of the population of Bangladesh, they are subordinate, marginalized and 'muted group' in terms of healthcare, decision making power, access to capital, social status and so on. Their voices, sorrows and burdens are confined at private sphere that can rarely be heard. This paper, however, aims to emphasize those voices who are silenced by the stereotypical norms and practices of this society but continues to bear the burden anyway.

Caroline Moser, in her book Gender Planning and Development: Theory, practice and Training (2012), developed a method of gender analysis at the Development Planning Unit in UK. At the heart of her framework is the idea of women's triple role. It involves mapping the division of labor regarding gender by asking one basic question- 'who does what?' Moser, in her analysis, explains three types of roles of women in general:

a. Reproductive works: These roles are labor intensive and time-consuming such as bearing, rearing and caring for offspring, maintenance and organization of household, caring household members, preparing and serving food, collecting water and fuel for home, family shopping etc.

b. Productive works: These roles are economic, and subsistence related such as employment, selfemployment, business, online earning etc.

c. Community works: These roles are social event and service related such as ceremonies and celebrations, local political activities, actions for the improvement of the community etc. Community works are divided into two types:

i. Community managing activities which are primarily maintaining scarce resources (water, healthcare and education) which everyone uses.

ii. Community politics which are primarily organizing formal or national politics. It involves pay money, enhance status and increase power.

These three sectors together are considered as the 'triple burden of women' by Moser. Thus, Moser's doctrine reveals that woman, in this universe, is not free of burden. In fact, their responsibilities in various aspects of life are responsible for their burden. Although Moser's framework is criticized for not capturing gender heterogeneity throughout the world, it remains useful for theorizing this study. In short, this paper took Moser's concept to show that working outside of home is another kind of burden for women alongside the burden of reproduction and community management.

Grounding on boundary theory which divides social life into work and family area, work-family conflict idea assumes that women experience incompatible demands between work and family roles (Greenhaus and others, 1985). In relation to this notion, the term 'motherhood penalty' is used to perceive disadvantages of working mother in the workplace while balancing home life. Unlike men and non-mothers, they need to prove themselves as dedicated and ideal workers. On the other hand, professional devotion is challenging when they try to maintain both roles properly. As a result, they face 'time poverty', a phenomenon used in the $20^{\text {th }}$ century Britain to describe the people who are 'money-rich' with sufficient income but 'time-poor' with little leisure time (Bardasi and Wodon, 2009). This paper shows that working women in Dhaka city experience work-family conflict. They face time poverty as they are more likely to be time poor than men due to having triple burden in their lives.

\section{METHODOLOGY}

The main objective of this study is to explore how urban working mothers in Dhaka city are experiencing triple burdens by performing their triple responsibilities during nationwide COVID-19 outbreak. In broad, there are some specific objectives of this work:

a. To identify the overall situation of urban working mothers in different areas of Dhaka city.

b. To depict the general socio-economic influences that change women's triple roles into their burdens.

c. To inquire the causes and consequences of triple burden experienced by women during COVID-19 pandemic in Bangladesh.

The present study an intensive work that relies heavily on qualitative research methods. In order to meet the objectives of this study, data were collected through both in-depth informal interviews with a free conversation on the topic and case study. Secondary sources such as newspaper, magazines, books, articles and online materials etc. are also used to relate data which are collected from primary sources. In this study 30 urban working mothers who live in different areas of Dhaka City are taken as sample by random sampling. Their age range is 21-55 years. They are from different socioeconomic profile, age group, perceptions and occupations such as teacher, banker, administrative officer, lawyer, garments worker, engineer, doctor, online entrepreneur, chef of restaurant, worker in beauty salons, migrant worker and NGO worker. They are chosen from both public and private job sectors. From ethical point of view, pseudonyms are used in case of mentioning them when needed. The total study period consists of exactly one year (20 March 2020- 20 March 2021) when COVID-19 hit Bangladesh on a large scale. 
The ethical Consideration of this study includes prior informed consent, anonymity and respect personal constraints. The researcher faced lots of challenges; among them the prime one is doing fieldwork during COVID-19 pandemic all over the country. Though this research mainly focused on face-toface conversation and case study, it also relied on telephone conversation due to an uneasy pandemic situation. During fieldwork, proper health cautions and social distance were major priorities of the researcher. However, pandemic environment made fieldwork situation was challenging and inaccessible to some informants. Since in-depth interview is time consuming and many of the respondents had a very busy schedule, thus could not always provide desired time and energy. Further, there is dearth of literature and research works on this topic particularly. However, this study can bring light to more academic research works and pave a new way of generating knowledge.

\section{RESULTS AND DISCUSSION}

Women's burden during any disaster such as famine, war, flood, disease outbreak etc. is a pandemic itself (Mondol, 2014). This scenario in the context of COVID-19 is no different. Though the physical impact of corona virus spares no one, it has disproportionately impacted women to a greater extent. In Bangladesh, it has potentially catastrophic impact on working women in general by adding more weight to their burden which is being discussed below:

\section{Women's Reproductive Role in COVID-19 Situation: First Burden}

It is almost always a woman who carries the heaviest of the reproductive burdens, along with additional roles that are universally imposed to them. Unfortunately, they seldom get any acknowledgement for their roles which they clearly deserve. It is a universal fact that women bear the loads of childbearing, rearing and caring along with the loads of their domestic works. These two universal roles increase their stress, anxiety, depression, rudeness, insomnia and many other mental disorders. Sometimes it is assumed that the first-time motherhood is the most difficult and after that the subsequent childcare becomes easier, due to the previous experience. The workload of a mother is not recognized properly, and nothing can truly prepare a woman for the job of motherhood. Besides, every journey of pregnancy is different, and every child is different in nature. Moreover, a new mother considers giving enough time to take care of herself instead of her newborn as a 'selfish' act. As a result, post-partum depression makes motherhood more stressful.

The journey of motherhood becomes a difficult part of their life during COVID-19 pandemic. World Health Organization has declared that the emergency responses to COVID related medical services have led to the negligence of other basic essential health services around the world. Lack of routine health care services, availability of medication, unavailability of doctor, nurses and other medical stuffs, scarcity of health information, insufficient PPE and other medical kits etc. during pandemic affects the quality of reproductive services. The absence of emergency medical help during childbirth often ends up causing delivering child at home, without appropriate medical support. Even for the women who gives birth child at the hospital, the situation is not any better.

Case Study-01: "Why are you here before testing for COVID$\underline{19 ? "}$

Dalia, a 40-year-old Government officer from Ramna, is a working mother who went through some serious complications during her second pregnancy. It was more than 5 years since her first child was born. Though she was going to her office daily, the water break during her second pregnancy made her to take leave from work. Due to coronavirus, her husband who is a businessman was hesitant to take her to a hospital to avoid the threat of getting infected by COVID-19. Hospitals are believed to be hubs of spreading the coronavirus, according to her husband. But as soon as her physical condition deteriorated, he was compelled to take her to a reputed maternity clinic. However, they refused services, suspecting her to be a COVID patient. Even after trying three more hospitals, they could not find any hospital to get the emergency delivery service that they so direly needed that moment. Finally, one hospital, which is at a long distance from her residence allowed her to get admitted for child delivery. Even for that admittance, she needed to get tested for COVID-19 before her admission to that hospital. This unwanted long suffering during a life and death emergency, broke her both physically and mentally. After having a critical cesarean delivery, when she again went there again for some follow up post-pregnancy checking, a hospital stuff was reluctant to provide services and asked, "Why are you here again if it is not an emergency?" However, it is a wellestablished fact that, a woman who went through post-natal complications and post-partum depression needs serious medical assistance.

The pandemic and the response to the pandemic are affecting medical services for women who have COVID-19 symptoms and thus refused to get services from the hospitals as they were assumed to be a COVID-19 infected patient (Gilbert et al 2020). Most of the hospitals in Bangladesh have either shut down or provided limited services during the outbreak. While minimizing reproductive health services, COVID-19 creates serious threat of disruptions in services related to unintended pregnancy management, safe abortion, maternal and neonatal mortality, post-pregnancy complications, sexually transmitted diseases and many more. For example, decline in the coverage of family planning, delivery and postnatal care caused sharp rise of maternal death during Ebola virus outbreak (20142016) in West Africa (Sochas, Chanon and Nam, 2017; Roberton 2020; Abbas et al 2020). In Dhaka city, some doctors have opted to provide online medical services only. But this came as no help to the peripheral, rural poor and uneducated women. Again, the marginalized, poor and single mothers were hit hardest by the economic crisis during the lockdown with the fear of losing job, getting partial or no 
salary, accompanied with huge workload. For example: lion's share of women from refugee communities of Rohingya in Ukhia, Cox's Bazar and ethnic minorities in Chittagong Hill Tracks (CHTs) face extreme challenges which are compounded by COVID-19. So, gender and reproductive issue during this pandemic must be taken into account.

Historically, it has always been women who have shouldered the duty of caregiver of her family members, sick and elderlies. If a woman is COVID-19 positive, she needs proper care and rest which she most possibly could not get due to housework. Even when she is not tested positive, she might need to take health risk to take care her family members who are COVID-19 positive. In addition to this, the scarcity of pediatricians and doctors during the lock down period creates enormous mental stress and burden for them. Also, the closure of school and playing with friends on both playground and home increases the additional work of day-long caring for the children. They also need to provide time and assistance to their children who have online classes and do not have private tutors.

Traditionally, it is generally women for whom household chores are meant to be. During the coronavirus pandemic many families have eliminated their temporary domestic workers ('chuta bua') to avoid community transmission and economic burden. So, women cannot but bear the additional responsibilities which was previously carried out by the housemaids. Although men are at home and are sharing some of the responsibilities, there is not much redistribution of some specific domestic works such as cooking, washing clothes, home cleaning etc.

\section{Case Study: "I do not get any time to take rest"}

Kamala is a middle-class working woman who runs her own beauty parlor. She is a well-known beautician at Uttara, Dhaka and just recruited some new workers for her parlor. While she is happy for what she is earning, she complains that they are nothing compared to her workload. Once the corona virus has arrived, she is facing long-term financial crisis as her customers are afraid of getting affected by the virus and avoid beauty parlors. Yet, she needs to run her business and provide salary for her employees. Again, her family decided to terminate the temporary housemaid due to the massive spread of COVID-19. So, Kamala needs to manage both her business and household chores at the same time. She clearly explained, "My 3 children keep me busy throughout the day. They eat, sleep and study on a different time schedule. So, I do not get any time to take rest. On the other hand, I need to manage my own business which I am rearing long like my own child. It is hard for me to accept that my old customers are not coming there even after trying to make it a safe zone during this pandemic. The coronavirus is killing my passion, savings, peace and happiness. This frustration along with household works significantly turned into big stress factor for me."

In a line, COVID-19 left women restless. However, some respondents who can work from home reported that they are happy as they have found some quality time with their children, husbands and family members which was nearly impossible before the outbreak. Also, new mothers who are service holders are blessed to have the opportunity to breastfeed their children.

\section{Women' Productive Work in COVID-19 Situation: Second Burden}

Bangladesh has long been performing better than other South Asian countries across many key development parameters. Among them, the contribution of women in productive sectors by employment, self-employment, trade or online business etc. is crucial one. Their participation in national economy contributes to their wellbeing, empowerment, freedom and rational decision-making power. However, they frequently face vulnerabilities at workplace which are rarely addressed. Moreover, their productive works are less visible, less secure and less valued compared to their male counterparts (Nawaz and McLaren, 2016).

Unlike non-working mothers, working mothers cannot fully enjoy the blessings of motherhood. It is sometimes considered as burden for them when it comes with the enormous workload. They face challenges at their workplaces during pregnancy and childbirth which extends throughout the whole period of raising their kids. Most importantly, they need to engage in workplace instead of fulfilling motherhood duties and domestic labor obligations. Though productive work makes women economically independent, working women habitually are blamed for not taking full-time responsibilities for their children. So, they feel self-imposed pressures while they compare themselves with those who are considered as 'good mothers' in the society. Again, when child gets sick, they feel extreme fear and anxiety if they cannot take leave from work or reach home late from office. It makes them guilty and frazzled. While office prioritizes work over family, women prioritize family over work. On the one hand, it limits their performance in workplace. On the other hand, it increases their workload, stress, anxiety and trauma with the threat of losing job.

Case Study: "We work, come home and then work again"

Ameena, a 37-year-old working mother, lives in Dhanmondi along with her husband and two years old son. She works in a renowned NGO with handsome salary. In the early morning she prepares food for her family. Before leaving for office, she feeds her baby and gets only few minutes to finish her breakfast with a cup of tea. Throughout her busy day at office, she takes care of her son over telephone. According to her, "It is really challenging and stressful to manage both home and work." After returning home from a hectic working day, she needs to spend some time her son. Then she prepares and serves dinner and spends some virtual time with her relatives and friends. She must go to bed early to maintain the same schedule of the next day. This is more or less, an inevitable reality for all working mothers across the country, as she said, "we work, come home and then work again". 
Thus, the division of attention between family and work is a burden for working mothers compared to those of nonworking mothers. This is just one of many similar cases. Moreover, job markets often refuse some necessary benefits for mothers such as shifting duty hours, exclusive breastfeeding opportunities, lactation consultation service, health insurance etc. As a result, many of them voluntarily left their job for the sake of their children without having any chance of regaining their lost job. For example, many female doctors in Bangladesh perform day-long duties in their professional life along with household works at the same time. As a result, Forbes Ferrante (2018) argued in a study that only $2 \%$ of working women take leave for family reasons and $43 \%$ of highly qualified women take leave after having a baby. This is mainly because women are expected to be available both at home and at workplace around the clock. It pushes them to make a choice between career and motherhood.

Case Study: "I could barely afford my dual role"

Alia is a 36-year-old mother who has a 7-month-old baby boy. He keeps her wake at night when everyone else is sleeping. She took 6 months of maternity leave from her office when her baby was born. But suddenly after joining at work, she became puzzled with her dual role: a mother as well as a banker at the same time. After a long busy day, some quiet time and sleep were the most desirable things for her which she could not get. Also, she added, "Every day the tension and challenge of balancing both office hour and family time makes me sleep deprived." This made hard for her to maintain both the career and the child. So, she said, "I could barely afford my dual role. I was banker, then left the job and started a career as an online entrepreneur and now I am neither."

In addition to work-family conflict, working women who remain busy throughout the day due to job commitments experience 'time poverty', translating as money-rich but timepoor. Again, they do not get enough time to spend some time for their own. So, they sacrifice their 'me' time in order to maintain their responsibilities. As a result, they lose their interest, passion, hobbies, self-care and relax time.

Case Study: "Sometimes I feel like having a life of a machine"

Dr. Farzana, a 40-year-old mother with prestigious job and social position, lives in Central Road with her 5 years old girl, husband and mother-in-law. During her student life, she always achieved height marks and scholarship. Her parents were ambitious about her future career. After graduation she opted for faculty position in a reputed University. Her husband who is also a faculty supported her throughout her career after their marriage. Dr. Farzana has always dreamed of a good carrier with adequate income. But at the same time, she has also craving for some quality time with her family and friends. She wants to spend more play time with her daughter who is growing up in care of her mother-in-law. She feels stress, emotional and guilty for leaving her baby at home and cannot be with her throughout the day. She also desires some private time for herself. Whenever she gets some free time, she reads books and poetry. Farzana said, 'Sometimes I feel like having a life of a machine.' She continued, 'After spending every rushed working day, I used to ask myself whether this is too much to ask for a little peace in life."

This case of Dr. Farzana is inevitable for most working women in Bangladesh. Most recently, people assume the newnormal 'work from home' phenomenon as easier than working in office. But more engagement in office work in a homely environment breaks attention in both office work and household roles. Home cannot always ensure proper working environment and interruption by family members make it difficult to keep concentration on work. Also, family members do not understand that 'work from home' requires same or sometimes more time, efforts and energy as working in the office. But again, there is always another side of the same coin. While it is challenging for some, it can be blessing for many as well. Working mother can spend more time at home, can get some relaxed time and can enjoy the company of their family members. But it is imperative to acknowledge all their hard work and the burden of responsibilities.

While work-family conflict is stressful for working mothers, the economic crisis of low-wage earning women during COVID-19 is hazardous. COVID-19 is responsible for global market crash, disrupted businesses and bankruptcy which has great impact on the economy of Bangladesh. Fortunately, the PM of Bangladesh announced a TK 72,500 core $(\$ 8.57$ billion) financial stimulus package on $5^{\text {th }}$ April (Farid, 2020). Unfortunately, not everyone is lucky enough to be blessed to get that package due to Bureaucratic long trail of papers. Thousands of women who belong to a middle-class economic background, are the worst affected because COVID-19 left them jobless and thus recently fall into poverty. Their foremost enemy is the burden of poverty and hunger. For example, a 35-year-old woman with 5 children attempted suicide on 12 April in Cox's Bazar. Because she and her husband were sacked without prior notice due to pandemic which translates to no income and no food. They did not receive any relief and could not bear to see her children starving (Griffiths, 2020; Bhuiyan et al 2020).

Over the last few months, the pandemic has negative economic impact on women who run small businesses and micro-entrepreneurship such as shops, restaurant, hotel, beauty salons, handicraft, boutique house etc. (Miller 2020). But those who have managed some motivations to work as online entrepreneur, have found online business as a financial blessing. Because now-a-days people prefer online shopping rather than going into a crowded marketplace. However, some women entrepreneurs face multidimensional problems due to lockdown such as delayed shipments, belated delivery policy, canceling previous order etc.

In Bangladesh, COVID-19 has wide-ranging impact on working women who had migrated in a hope of getting better opportunity, income and livelihood. Bangladesh experience rapid rural-urban migration with 43 million urban populations 
in 2010 (World Population Prospects, 2019). During the entire lockdown period, many women who were previously working as domestic workers or garment laborers, have lost their job, income and thus food security (UN Women, 2020). Women who are part-time employee or whose husbands are migrant workers, are afraid of salary cut down. The following case study elaborates some similar condition of a respondent:

Case Study: "COVID-19 is like a double-edged sword for me, cutting me down both financially and mentally."

A 25-year-old newly married garments worker Rokeya lives in a busy area of the capital city in Bangladesh for 5 years with her elder sister who also works in the same industry. After the outbreak, their garment remained closed for uncertain period. This situation brought financial crisis along with the tension of uncertain future. Without getting any hope for a new income source, she got the news that her husband who was a migrant worker has returned from Abu Dhabi. Her husband had lost his job due to COVID-19 and has returned home with a financial crisis, depression and sickness. Also, since the return he has been boycotted by his suspicious community who has unknowingly identified him as a carrier of coronavirus. This situation makes it difficult to find a new job for him. So, she explained, "COVID-19 is like a double-edged sword for me, cutting me down both financially and mentally."

\section{Women's Community Works in COVID-19 Situation: Third Burden}

The mankind all over the world has stumbled into a huge consternation over the last few months due to COVID-19 pandemic. Like Ebola outbreak, the indirect impact of COVID-19 is more serious than the outbreak itself (Elston et al, 2017). Over the past couple of months, it has propelled women to home-confinement. While mingling with the newnormal life by adapting home quarantine, social distancing, self-isolation etc., a regular communication with friends, relatives and community people has become highly troublesome. In such unfortunate situation, they are unhappily trapped at home after movement restriction and country-wide lockdown came to in effect.

In the context of present situation, corona virus hinders the wellbeing, safety and advancement of women. This lifethreating virus affects social life, economic sustainability and physical and mental health, including lack of medical care, stress, fear, anger, depression, loneliness etc. (Mukhtar 2020). By nature, women love to spend their idle time by doing things like shopping or roaming around. During COVID-19 pandemic shopping from a physical market is risky as it provokes community transmission. While online shopping saves time and energy but some women enjoy physical roaming and shopping rather than fulfilling their needs from online marketplace. During the lockdown period, social distance increases with the frequency of phone calling, video calling, chatting etc. which has both positive and negative sides. Though it makes social relationship easy, it fails to create the emotion of face-to-face conversation. Women from lower economic group are deprived of the virtual communication and thus burdened with a complete lockdown. Also, spending too much time on electronic devices such as cell phone, laptop, internet browsing, TV are harmful for both physical and mental health. The change of lifelong lifestyle has negative impact on many women.

Case Study: "I miss my old me. I want my old lifestyle back."

Aysha was an extrovert girl before completing graduation. She always dreamt to be a fashion designer. But suddenly after completing her study, her father influenced her to get herself admitted into a reputed law college. Now, at the age of 46 , she is a renowned lawyer. She is a full-time working woman and a mother of two teenage girls. Throughout her motherhood, she has invested much of her time for her girls in a hope that one day they will become lawyers like her. Her husband is also a lawyer, and both need to work hard for their own career. After returning home from work, they always try to manage some time for their girls. On every weekend they used to take them to a park or a dinner treat. Sometimes their relatives and friends used to meet their daughters. She told, "We were living happily altogether. But it seems that such time has come to an end." Since the outbreak of coronavirus requires to spend more time on laptop due to 'work from home' purposes. On the other hand, their girls remain busy all day with Facebooking and online classes. This sudden change has hampered her familiar lifestyle which she has been following for a very long time. Aysha thus agonizingly told that "I miss my old me. I want my old lifestyle back. This lonely quarantined and nonhuman technological life brings no peace. The saddest part is that we do not even know how long we will need to stay in like this."

The effects of COVID-19 pandemic are not limited to socioeconomic aspects, but also extended to domestic violence during the lockdown. United Nations called domestic violence against women as a 'Shadow Pandemic'. In France, domestic violence has increased by $30 \%$ since the lockdown on March 17, 2020 (UN Women, 2020). In the context of Bangladesh, this result is no different. One respondent, Nelima from Mohammadpur, was completely afraid of lockdown since she was trapped with an abuser husband and in-laws. While men lose income and fall into poverty, children are locked at home, other family members could not meet their dear ones, women are thought to be the weak one, who are easy targets for venting their angers on. The effect of such violence is immense on women's mental health.

Unlike the non-working women, the community roles of working women are troublesome. The female front-line fighters of COVID-19 are risking their lives for the shake of the betterment of their community. Until October 15, 2020, around 2,839 doctors have been affected and 100 of them demised from COVID-19 (Dhaka Tribune, 2020). Also, doctor and healthcare workers are at huge risk of getting infected and transmitting the virus to their family. The case of a doctor is being given below: 
Case Study: "For who we are risking our lives, keep distance with our children, destroying our sleeping time and wasting our energy?"

Samina, a senior Pulmonologist, working at a well-known hospital in Mirpur, is currently posted in the hospital's COVID unit. What is being a burden for her, is not the life risk for her own, rather for her family. She has a college going girl and a school going boy. Moreover, she lives with her husband who is diabetic, and she has older parents who live with her at home. So, the health risk of her family is clearly immense. This fear and anxiety cause additional mental burden on her at a regular basis. According to her, working for the nation is her duty. While it is an honor for her, it is also creating a lot of trouble for her. She became frustrated by thinking whether it is worth to work for the community of people who are not conscious at all about their own safely, who frequently violates COVID related safety regulations in public, even often refusing to use simple facemask. Considering the situation, she leaves an open question, "For who we are risking our lives, keeping distance with our children, destroying our sleeping time and wasting our energy?"

\section{CONCLUSION}

Women in Bangladesh have traditionally been performing multiple roles that constantly came into conflict with one another which has so far been an unexcavated area for social science research. Nevertheless, the bridge that connects almost every woman from different occupation throughout the world is the immense workload during this COVID-19 situation. It effects their physical, mental and social wellbeing at the same time. Though the pandemic is not bound to any specific group of people nor their gender, it has affected the women severely. This research shows that unlike non-working mothers, working mothers of Bangladesh experience triple burdens during the pandemic situation. While the first burden is the journey of motherhood and loads of domestic chores, the second burden is to maintain their workplace at the same time. The third burden is the community works which are traditionally imposed to them. In a nutshell, it is a real hard job to pave a precise way of balancing among the workloads of working women during ongoing pandemic situation.

\section{FUTURE RESEARCH}

This paper can contribute to social science academia by introducing thought provoking gender related issues such as portraying the status of women in developing countries, a cross-cultural comparison among the experience of women from different countries, exploring the emergency pandemic responses regarding gender related issues, focusing mental health of women during an outbreak, generating gender related policies and many more.

\section{REFERENCES}

[1] Abbas, K., Procter, S. R., van Zandvoort, K., Clark, A., Funk, S., Mengistu, T., ... \& Medley, G. (2020). Routine childhood immunisation during the COVID-19 pandemic in Africa: a benefit-risk analysis of health benefits versus excess risk of SARS-CoV-2 infection. The Lancet Global Health, 8(10), e1264e1272.

[2] Akhter F. (2020). COVID-19 and healthcare denial. New Age, Retrived from 24 April, 2020 https://www.newagebd.net/article/103590/covid-19-andhealthcare-denial. Accessed.

[3] Aldoory, L., Jiang, H., Toth, E. L., \& Sha, B. L. (2008). Is it still just a women's issue? A study of work-life balance among men and women in public relations. Public Relations Journal, 2(4), 120.

[4] Alon, T., Doepke, M., Olmstead-Rumsey, J., \& Tertilt, M. (2020). The impact of the coronavirus pandemic on gender equality. Covid Economics Vetted and Real-Time Papers, (4).

[5] Alon, T. M., Doepke, M., Olmstead-Rumsey, J., \& Tertilt, M. (2020). The impact of COVID-19 on gender equality (No. w26947). National Bureau of Economic Research.

[6] Ardener, S. (2005). Ardener's" Muted Groups": The genesis of an idea and its praxis. Women and Language, 28(2), 50.

[7] Arntz, M., Yahmed, S. B., \& Berlingieri, F. (2020). Working from Home and COVID-19: The Chances and Risks for Gender Gaps. Intereconomics, 55(6), 381-386.

[8] Bardasi, E., \& Wodon, Q. (2009). Working long hours and having no choice: Time poverty in Guinea. The World Bank.

[9] Bhuiyan, A.K.M.I., Sakib, N., Pakpour, A.H. et al. COVID-19 (2020) Related Suicides in Bangladesh Due to Lockdown and Economic Factors: Case Study Evidence from Media Reports. Int J Ment Health Addiction . https://doi.org/10.1007/s11469-02000307-y

[10] Boca, D. D., Oggero, N., Profeta, P., \& Rossi, M. (2020). Women's work, housework and childcare, before and during COVID-19.

[11] Bond, S. (2002). Family-friendly Working?. Putting Policy Into Action. Associated University Presse.

[12] Dashraath, P., Jeslyn, W. J. L., Karen, L. M. X., Min, L. L., Sarah, L., Biswas, A., ... \& Lin, S. L. (2020). Coronavirus disease 2019 (COVID-19) pandemic and pregnancy. American journal of obstetrics and gynecology.

[13] Dhaka Tribune. (2020). Bangladesh sees 100th death of doctors from Covid-1. Retrieved from: https://www.dhakatribune.com/health/coronavirus/2020/10/15/ban gladesh-sees-100th-death-of-doctors-from-covid-19

[14] Dickson, E. J. (2020). Coronavirus is killing the working mother. Rolling Stone.

[15] Elston, J. W., Cartwright, C., Ndumbi, P., \& Wright, J. (2017). The health impact of the 2014-15 Ebola outbreak. Public health, 143, 60-70.

[16] Farid, Z. I. (2020). Experience and perception of urban community towards COVID-19 pandemic. International Journal of Natural and Social Sciences, 7(4), 94-102.

[17] Feng, Z., \& Savani, K. (2020). Covid-19 created a gender gap in perceived work productivity and job satisfaction: implications for dual-career parents working from home. Gender in Management: An International Journal.

[18] Ferrante, M. B. (2018). A look into the best and worst paid family leave policies. Forbes.

[19] GAZI, A. K. COVID-19: AN ANALYSIS OF THE IMPACTS OF NATIONAL LOCKDOWN ON WOMEN.

[20] Ghosh R, Dubey MJ, Chatterjee S, Dubey S. (2020). Impact of COVID-19 on children: special focus on the psychosocial aspect. Minerva Pediatr 72:226-235. DOI: $10.23736 /$ S00264946.20.05887-9

[21] Gilbert M, Pullano G, Pinotti F, et al. (2020). Preparedness and vulnerability of Af rican countries against importations of COVID-19: a modelling study. Lancet 395(10227), 871-877. https://doi.org/10.1016/S0140-6736(20)30411-6

[22] Greenhaus, J. H., \& Beutell, N. J. (1985). Sources of conflict between work and family roles. Academy of management review, 10(1), 76-88.

[23] Griffiths, M. (2020). COVID-19-related suicides in Bangladesh due to lockdown and economic factors: Case study evidence. 
[24] Grimshaw, L. (2011). Community work as women's work? The gendering of English neighbourhood partnerships. Community Development Journal, 46(3), 327-340.

[25] Government of Bangladesh. (2021). COVID-19 Tracker. Retrieved from: http://covid19tracker.gov.bd/\#tab_1_4

[26] Islam, A. (2020). COVID-19 lockdown increases domestic violence in Bangladesh. Retrieve from: https://www. $d w$. com/en/covid-19-lockdown-increases-domestic-violence-inbangladesh/a-53411507.

[27] Lyon, S., Mutersbaugh, T., \& Worthen, H. (2017). The triple burden: The impact of time poverty on women's participation in coffee producer organizational governance in Mexico. Agriculture and Human Values, 34(2), 317-331.

[28] Johns Hopkins University. (2021). COVID-19 Dashboard. Center for Systems Science and Engineering.

[29] [29] Mamun, M. A., Bodrud-Doza, M., \& Griffiths, M. D. (2020). Hospital suicide due to non-treatment by healthcare staff fearing COVID-19 infection in Bangladesh?. Asian journal of psychiatry, 54, 102295.

[30] McLaren, H. J., Wong, K. R., Nguyen, K. N., \& Mahamadachchi, K. N. D. (2020). Covid-19 and Women's Triple Burden: Vignettes from Sri Lanka, Malaysia, Vietnam and Australia. Social Sciences, 9(5), 87.

[31] Miller, J. (2020). COVID-19 has hit women hard, especially working mothers. Retrieve from: https://news.usc.edu/171617/covid-19-women-job-losseschildcaremental-health-usc-study/ (Accessed 25 August 2020).

[32] Mondal, S. H. (2014). Women's vulnerabilities due to the impact of climate change: Case from Satkhira region of Bangladesh. Global J Hum Soc Sci, 14(5), 46-52.

[33] Moore, H. L. (1988). Feminism and anthropology. U of Minnesota Press.

[34] Moser, C. (2012). Gender planning and development: Theory, practice and training. Routledge.

[35] Mukhtar, MS. (2020). Mental health and psychosocial aspects of coronavirus outbreak in Pakistan: psychological intervention for public mental health crisis. Asian Journal of Psychiatry, 51, e102069

[36] Nawaz, F., \& McLaren, H. J. (2016). Silencing the hardship: Bangladeshi women, microfinance and reproductive work. Social Alternatives, 35(1), 19.

[37] Noor, N. M. (2004). Work-family conflict, work-and family-role salience, and women's well-being. The Journal of social psychology, 144(4), 389-406.

[38] Ortner, S. B. (1972). Is female to male as nature is to culture?. Feminist studies, 1(2), 5-31.

[39] Power, K. (2020). The COVID-19 pandemic has increased the care burden of women and families. Sustainability: Science, Practice and Policy, 16(1), 67-73.
[40] Raihan, Selim, \& Bidisha, Sayema Haque. (2018). Female employment stagnation in Bangladesh. A research paper on Economic Dialogue on Inclusive Growth in Bangladesh.

[41] Roberton, T., Carter, E. D., Chou, V. B., Stegmuller, A. R., Jackson, B. D., Tam, Y., ... \& Walker, N. (2020). Early estimates of the indirect effects of the COVID-19 pandemic on maternal and child mortality in low-income and middle-income countries: a modelling study. The Lancet Global Health, 8(7), e901-e908.

[42] Rogers, B. (2005). The domestication of women: Discrimination in developing societies. Routledge.

[43] Spinelli, M., Lionetti, F., Pastore, M., \& Fasolo, M. (2020). Parents' stress and children's psychological problems in families facing the COVID-19 outbreak in Italy. Frontiers in Psychology, 11, 1713.

[44] Sochas, L., Channon, A. A., \& Nam, S. (2017). Counting indirect crisis-related deaths in the context of a low-resilience health system: the case of maternal and neonatal health during the Ebola epidemic in Sierra Leone. Health policy and planning, 32(suppl_3), iii32-iii39.

[45] UN Women. (2020). Far from the spotlight, women workers are among the hardest hit by COVID-19 in Bangladesh. Retrieved from: https://www.unwomen.org/en/news/stories/2020/4/featurewomen-workers-hardest-hit-by-covid-19-in bangladesh? fbclid=IwAR2EOcV6RSgmIdetFk08HGgFm31stJyQvLvxxUVjuN 0vnXo5JDQRt-mFGao . (Accessed August 26, 2020)

[46] UN Women. (2020). The COVID-19 Shadow Pandemic: Domestic Violence in the World of Work - A Call to Action for the Private Sector. Retrieved from: https://www.weps.org/resource/covid-19shadow-pandemic-domestic-violence-world-work-call-actionprivate-sector

[47] Wenham, C., Smith, J., \& Morgan, R. (2020). COVID-19: the gendered impacts of the outbreak. The Lancet, 395(10227), 846848.

[48] Wodon, Q., \& Blackden, C. M. (Eds.). (2006). Gender, time use, and poverty in sub-Saharan Africa. The World Bank.

[49] World Economic Outlook database. (2021). International Monetary Fund. Retrieved from: https://www.imf.org/en/Publications/WEO/weodatabase/2021/April/weoreport?c=513,\&s=NGDPD,PPPGDP,NGDPDPC,PPPPC,\&sy=201 $9 \&$ ey $=2026 \&$ ssm $=0 \& \mathrm{scsm}=1 \& \mathrm{scc}=0 \& \mathrm{ssd}=1 \& \mathrm{ssc}=0 \& \mathrm{sic}=0 \&$ sort $=$ country $\& d s=. \& b r=1$

[50] World Population Prospects. (2019). United Nations Population Division. Retrieved from: https://data.worldbank.org/indicator/SP.POP.TOTL.FE.ZS?locatio $\mathrm{ns}=\mathrm{BD}$

[51] Zamarro, G., Perez-Arce, F., \& Prados, M. J. (2020). Gender Differences in the Impact of COVID-19. Working Paper. Switzerland: Frontiers in Public Health. Retrieved from https://tinyurl. com/CESRGenderDiffs. 